\title{
The Hybridity of Inclusive Innovation Narratives Between Theory and Practice: A Framing Analysis
}

\author{
Felix Ouko Opola ${ }^{1}$ (D) $\cdot$ Laurens Klerkx $^{1} \cdot$ Cees Leeuwis ${ }^{1} \cdot$ Catherine W. Kilelu $^{2}$
}

Published online: 23 June 2020

(C) The Author(s) 2020

\begin{abstract}
Inclusive innovation remains an under-conceptualised and ambiguous concept despite garnering political and academic interest in recent decades. This paper explores the narratives of inclusive innovation that exist in literature and how these are framed in practice, using a case study of the Kenyan agricultural sector. Findings indicate that while there is significant similarity between the theoretical and empirical framing of the concept, there are also stark differences. In addition, different actors such as the state, development agencies, the private sector or universities do not fully ascribe to any of the existing theoretical narratives on inclusive innovation. Instead, they frame it based on their own contexts, mandate and interests using concepts borrowed from existing theoretical narratives. This indicates that instead of a grand theory of inclusive innovation that applies universally, there are several ways of enacting inclusive innovation. This also limits the transferability of a onesize-fits-all model of inclusive innovation.
\end{abstract}

Keywords Inclusive innovation · Frugal innovation · Grassroots innovation · Bottom of the pyramid · Inclusive development · Inclusive business · Social innovation ·

Kenya

\section{Résumé}

L'innovation inclusive reste un concept sous-développé et ambigu en dépit de l'intérêt politique et académique qu'il a suscité au cours des dernières décennies. Cet article explore les discours sur l'innovation inclusive qui existent dans la littérature et la façon dont ces discours sont mis en pratique, en utilisant une étude de cas sur le secteur agricole kenyan. Les résultats indiquent que, s'il existe une similitude significative entre le cadre théorique et le cadre empirique du concept, il existe également des différences marquées. En outre, différents acteurs tels que l'État, les agences de

Felix Ouko Opola

felix.opola@wur.nl; felix.opola@gmail.com

1 Knowledge, Technology and Innovation Group, Wageningen University, Wageningen, The Netherlands

2 3R project, African Centre for Technology Studies, Nairobi, Kenya

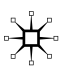


développement, le secteur privé ou les universités ne souscrivent pleinement à aucun des discours théoriques existants sur l'innovation inclusive. Au lieu de cela, ils le présentent selon leurs propres contextes, mandats et intérêts en utilisant des concepts empruntés aux récits théoriques existants. Cela indique que plutôt qu'une grande théorie de l'innovation inclusive qui s'applique de manière universelle, il existe plusieurs façons de mettre en œuvre l'innovation inclusive. Cela limite également la transférabilité d'un modèle unique d'innovation inclusive.

\section{Introduction}

Innovation can be conceived as a process of change, where new or modified knowledge, expertise, social arrangements or technologies are applied to solve various challenges in society (Kilelu et al. 2014; Swaans et al. 2014). The significance of innovation in providing solutions to social problems such as income inequality and food insecurity has been emphasised in the recent past (Banks et al. 2015; Baud 2016; Rip 2018). For instance, the African Union's Agenda 2063 acknowledges that the achievement of the continent's development goals is linked to innovation in critical areas such as agriculture, health and energy (African Union Commission 2014). However, there have been concerns over the exclusive nature of the innovation process and its tendency to marginalise actors with less resource endowments (Chataway et al. 2014). As a response, the past few decades have witnessed an emphasis on innovation processes that are compatible with the constraints and opportunities that are faced by those who are side-lined in the innovation process such as individuals and organisations in the informal sector, in remote areas or those with little resource endowments (Chataway et al. 2014; Heeks et al. 2014; Kanu et al. 2014). Such a process has been captured in concepts such as social innovation (Altuna et al. 2015), frugal innovation (Knorringa et al. 2016), bottom of the pyramid innovation (Prahalad et al. 2012; Peredo et al. 2017), pro-poor innovation (Stott and Tracey 2018), grassroots innovation (Smith et al. 2014; Hossain 2016) or, more broadly, inclusive innovation (Chataway et al. 2014; Heeks et al. 2014; Pansera and Owen 2018), the term which will be henceforth used in this paper.

The concept of inclusive innovation is perceived as a new paradigm within development narratives (Pansera and Owen 2018). However, despite the increased usage of the term, it remains an ambiguous concept with multiple interpretations from different political actors and academic disciplines (Pansera and Owen 2018). This has significant implications as theoretical models usually influence how development policy and interventions are designed and implemented (Bryden et al. 2017; Godin 2017). For instance, multi-stakeholder partnerships may be hindered by actors who adhere to different logics with varying normative assumptions and values when perceiving a problem or solution (Heeks et al. 2020; Levidow and Papaioannou 2017; Osei-Amponsah et al. 2018). A study of development co-operation between Brazil and Ghana revealed that within the partnership, Brazil's government was concerned with low tillage conservation agriculture, while, in contrast, the Ghanaian government was keen on a pathway that led to a highly mechanised agriculture (Cabral 2016). It has been suggested that an elaborated theory of inclusive innovation is 
required in order to accommodate all the differing logics and perspectives regarding inclusive innovation and the problems and solutions that are being highlighted (Klochikhin 2012; Gupta et al. 2015).

In communication sciences literature, it has been pointed out that through language and symbols, individuals and organisations highlight certain aspects of an issue either due to their backgrounds and experiences or because they would like to promote a certain interest or agenda (Entman 1993; Cacciatore et al. 2016). In line with framing literature that explores this discursive process (Dewulf et al. 2009), it can be expected that there exists different narratives about inclusive innovation. Gee (2014) defines a narrative as the linguistic device through which people make sense of the problems that concern them and their attempts to resolve these problems. A narrative of inclusive innovation, therefore, includes how exclusion is constructed as a problem within the innovation process and what solutions innovation can provide for inclusion. There is limited systematic analysis of what these narratives are both in theory and empirically as well as their implications for innovation and social inclusion practises (Pansera and Owen 2018). This is a knowledge gap that this paper aims to address.

Using framing analysis (Entman 1993; Dewulf et al. 2009) as a methodological guide, we explore the narratives of inclusive innovation that exist in the literature as well as within the Kenyan agricultural sector. We focus our analysis on the Kenyan agricultural sector for several reasons. First, it is characterised by diverse organisations that are engaged in the development or modification of knowledge, technologies and social arrangements including state agencies, NGO's, research institutions and commercial enterprises (Christoplos 2010; Banks et al. 2015). We use 'organisations' as a broad concept that encompasses these types of actors. Secondly, social inclusion is one of the key anchors in the current government 10-year strategic plan for agriculture in the country that stipulates how the sector can be transformed to benefit more that 3 million farming households and increase the resilience of farmers in areas with poor climate (MoALF 2019). Finally, the sector is dynamic and unpredictable with new approaches to innovation and social inclusion being experimented by different public and private organisations (Kilelu et al. 2014). Our aim is to answer the following two questions: (a) How is inclusive innovation framed by organisations in the Kenyan agricultural sector? and (b) How do these empirical frames relate to existing theoretical narratives about inclusive innovation?

In the next section, we provide a detailed analysis of how the concept of inclusive innovation is framed in the existing literature in order to develop an analytical framework for exploring the empirical framing of the concept.

\section{Three Theoretical Narratives of Inclusive Innovation}

Though the social consequences of innovation has been a long-standing concern (Tracey and Stott 2017), the concept of inclusive innovation has garnered interest in development of innovation literature over the past two decades (Chataway et al. 2014; Pansera and Owen 2018). We identify three distinct narratives that have 
emerged regarding how the concept is framed or defined: A bottom of the pyramid (BOP) narrative, a grassroots narrative and a political economy narrative as summarised in Table 1 below.

\section{The BOP Narrative}

\section{The Problem of Exclusion}

This narrative stipulates that producers and consumers at the bottom of the economic pyramid have been neglected by the private sector due to minimal returns (Prahalad 2005; Danse et al. 2020). Common in inclusive business and management literature, it considers the problem of exclusion as the hindrance BOP actors face from actively participating in commodity, labour, financial, and other markets either as producers or consumers (Chataway et al. 2014; Knorringa et al. 2016; Higgins and Richards 2019).

\section{Causes of Exclusion}

Resource scarcity at the BOP is thought to be a key reason for their exclusion from the innovation process. It's argued that innovation is a skill and capital intensive process and that BOP consumers and producers lack the material and immaterial resources for innovation (Pansera and Sarkar 2016; Pansera and Martinez 2017). In addition, it is pointed out that private companies have shied away from the BOP market segment due to low returns on investment thus excluding them from various markets (Prahalad 2005).

\section{Recommended Solutions}

Inclusive innovation within this narrative is perceived as the means by which the challenge of resource constraints at the BOP can be overcome through market-based solutions that link BOP actors to existing markets. Concepts such as frugal innovation and social entrepreneurship (Knorringa et al. 2016; Venot 2016; Higgins and Richards 2019) that emphasise the role of multinational and local business enterprises in providing solutions to resource constraints at the BOP emerged from this literature. A new strand of BOP literature goes beyond the provision of goods and services and emphasises co-innovation with BOP actors as a way to include them in the innovation process (Simanis and Hart 2011; Chataway et al. 2014).

\section{The Grassroots Narrative}

\section{The Problem of Exclusion}

According to this narrative, the problem is that innovation processes prioritise formal or 'scientific' knowledge and practises over local or informal forms of knowledge and practises (Fressoli et al. 2014; Pansera and Martinez 2017). For instance, 


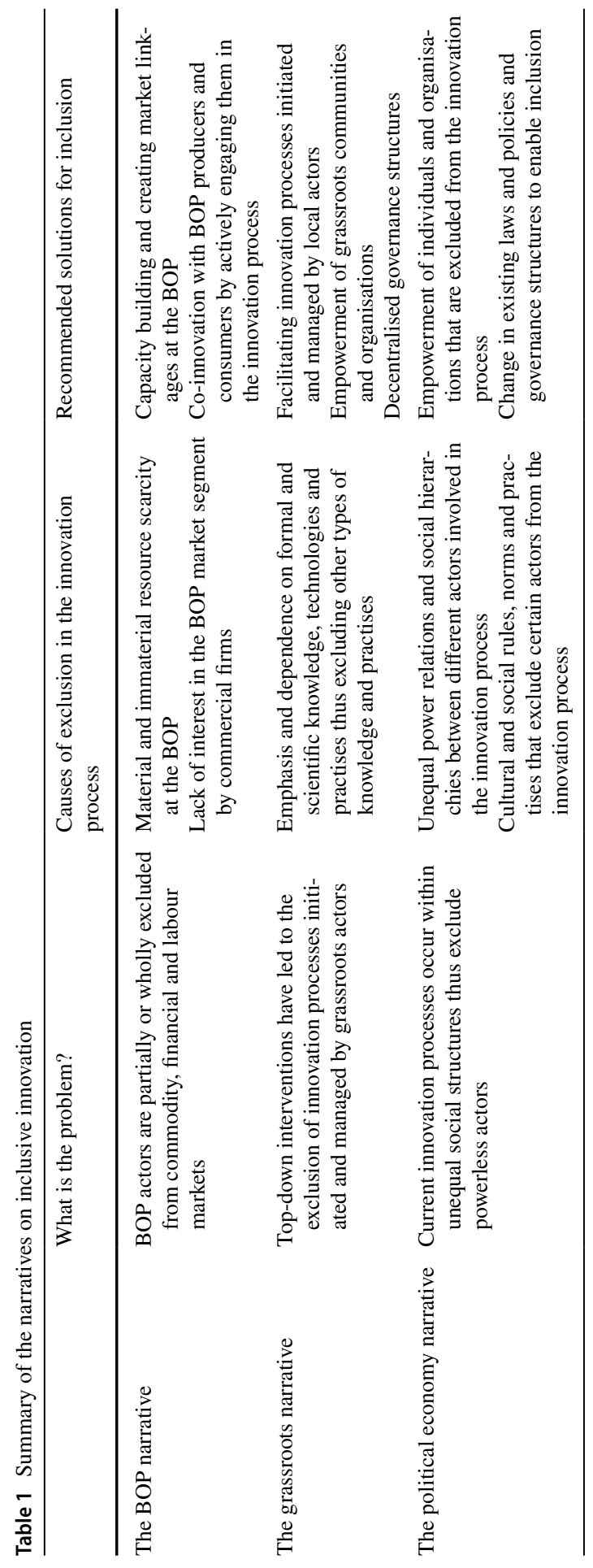

我这 
skills, knowledge and technologies from the informal sector, and rural areas or arid lands may be excluded from official development planning and practises (Arza and van Zwanenberg 2014; Cozzens and Sutz 2014; Stott and Tracey 2018).

\section{Causes of Exclusion}

The cause of such exclusion is thought to be top-down innovation processes due to the fact that the technology-push model is a well-established and relatively less costly model of innovation (Stoop and Hart 2005; Minh et al. 2014). As a result, such interventions are not compatible with the priorities, needs and interests of local communities (Moschitz et al. 2015).

\section{Recommended Solutions}

Grassroots-based innovation processes emphasise knowledge, practises and technologies that are initiated and managed by local communities or organisations that are not hindered by formal understanding of the innovation process (Smith et al. 2014). Despite of and even due to financial and other constraints, farmers, traders and other actors at the grassroots are thought to be innovative in developing solutions to the social and economic challenges they face (Swigert-Gacheru 2011; Karanja et al. 2017). According to this narrative, external actors should, therefore, find ways of aligning official development planning and interventions to these grassroots initiatives, priorities and innovations rather than impose new forms of knowledge, practises and technologies (Minh et al. 2014).

\section{The Political Economy Narrative}

\section{The Problem of Exclusion}

This narrative stipulates that rules and practises in any society embody the interests of those actors with influence and authority over how resources are allocated, accessed and used (Illich 1973). Studies have revealed how new expertise or technologies and other resources have been subject to capture and control by elite individuals and organisations (e.g. Kenis and Mathijs 2014; Lowe et al. 2019; Parkinson 2009). Innovation may, therefore, be used as a tool to achieve certain agendas and interest of the elite and, therefore, excluding the needs and interests of other actors (Illich 1973; Arora and Romijn 2012; Borda-Rodriguez and Johnson 2019).

\section{Causes of Exclusion}

Exclusion in the innovation process, according to this narrative, is due to the tendency of the innovation process to respond to the needs and interests of actors who have influence and control over allocation of resources (Merrey and Cook 2012; Nemes and Augustyn 2017). As a result, the development of and control over knowledge, practises and technologies is dominated by influential actors in politics, 
business and even within local communities (Arora and Romijn 2012; Poole et al. 2013; Rusca et al. 2015; Borda-Rodriguez and Johnson 2019).

\section{Recommended Solutions}

The political economy perspective advocates for broad-based systemic change and social transitions with the state and public organisations as key drivers of an inclusive innovation process (Arora and Romijn 2012; Poole et al. 2013; Onsongo and Schot 2017). Solutions that are social in nature such as multi-actor partnerships, decentralised systems of governance and new policies and regulations are emphasised as a means by which power imbalances can be overcome and the marginalised can participate in the design and implementation of new expertise, knowledge and technologies (Heeks et al. 2014; Osei-Amponsah et al. 2018). Tracey and Stott $(2017$, p. 58) point out that innovation in marginalised spaces require a novel approach and that 'social innovation' can be a means by which new organisational arrangements that embody the interests of marginalised actors are developed.

When looking closely at the three narratives presented, they differ along two relatively independent axes or dimensions regarding how problems and solutions are constructed. The first axis (horizontal axis in Fig. 1a, b below) contains the role of the private sector on one end and the role of the public sector-including public organisations and individual citizens - on the other end. The second axis (vertical) comprise the value of local initiative, knowledge and capacity on one end and value of external initiative, knowledge and capacity on the other. In Fig. 1a and b below, we have mapped these two axes in terms of how theoretical narratives construct the problem (Fig. 1a) and the solution recommended (Fig. 1b).

As noted in Fig. 1a and b, the three narratives are somewhat coherent in the sense that the solutions presented mirror the opposite of how the problem is perceived. The BOP narrative constructs the problem as inadequate or missing local capacity, knowledge and expertise, but emphasises solutions provided by external actors. Similarly, the grassroots narrative locates the problem within external capacities, knowledge and expertise that are thought to be exclusive of local contexts. It, however, emphasises locally initiated solutions and knowledge. In the remainder of this paper, we present our methodology and methods for the study before presenting the findings, followed by a discussion and conclusion sections.

\section{Methodology}

\section{Framing and Framing Analysis}

We use framing analysis to unravel how organisations within the Kenyan agricultural sector construct meanings and explanations about the concept of inclusive innovation. For instance, a certain issue or event may be interpreted and framed differently by a government agency, research institution or commercial enterprise owing to differences in their backgrounds, objectives and interests (Thornton et al. 2012). Framing involves construction of different elements of 


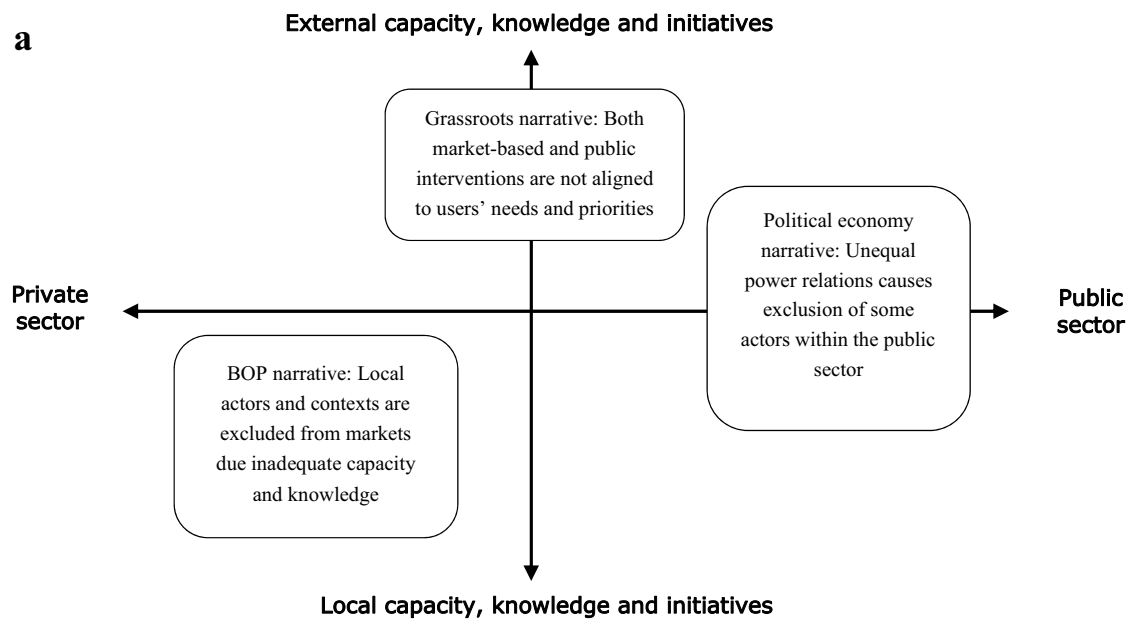

b

External capacity, knowledge and initiatives

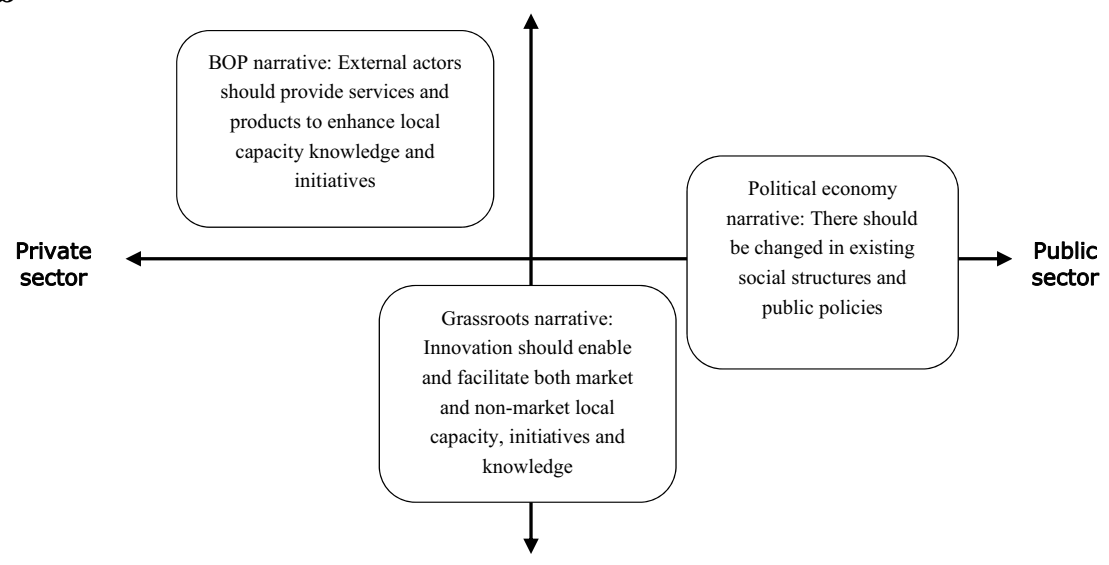

Local capacity, knowledge and initiatives

Fig. 1 a How the problem is defined. b Recommended solutions

an issue which may include a problem, cause of the problem and recommended solutions (Entman 1993). When brought together, these aspects form a broad narrative about the issue or what Campbell and Docherty (2003) refer to as whole story frames. Within these frames, some apects of the issue or problem may be emphasised, while other aspects are downplayed or ignored depending on the objectives and mandate of the organisation that ascribe to the frame (De Bruycker 2017). 


\section{Data Collection and Analysis}

Data were collected through in-depth interviews and participation in various workshops and seminars. Since the aim of the study was to investigate how language is used to frame social phenomena, these data collection methods were useful for exploring how organisations framed the issue of inclusive innovation during interactions with each other and with the researcher. Organisations were sampled based on their involvement in innovative initiatives such as research, training and advisory services for farmers and other actors, new business model development, development and dissemination of technologies and facilitating new social relationships and arrangements. Additionally, they were selected for having a social inclusion objective in the design and implementation of their programs. Sampling was done to achieve maximum variation on the types of organisations present in the sector. Eventually, a total of 29 in-depth interviews were conducted with different organisations and development programmes between February and July 2018. Table 2 below is a summary of the respondents from the interviews and the range of organisations they were drawn from. Public agencies interviewed were a training and vocational institute, three government research institutes and two local governments. Civil society organisations represented in the study were three development agency programmes and four NGOs. The private companies included three international companies and nine Kenyan companies, while the two universities chosen for the study both had agricultural extension and outreach programmes.

This data were complemented by notes and observations from six workshops and seminars organised by government agencies, development agencies and private sector alliances which were attended. These included a dairy investor's forum, two seminars on sustainable inclusive business, an annual scientific symposium on animal production, an aquaculture stakeholders meeting and an inclusive trade workshop.

The elements and axes in the three theoretical narratives of inclusive innovation were used as sensitising concepts during the coding of the data and to develop a coding scheme (Strauss and Corbin 1990). The data were coded both deductively and inductively with the assistance of the Atlas.TI data analysis programme. Each paragraph of data was 'decontextualized' from its setting in the first step of analysis (Tesch 1990, p. 115) by asking questions such as what innovation processes are being refered to? How is the problem of exclusion in an innovation process being defined and what are being recommended as the solutions? A total of 65 different codes and concepts were developed during coding. These concepts were later grouped and clustered to form the whole story frames or narratives. In the next section, we present the frames of inclusive innovation that emerged from our data and later compare these to the theoretical narratives.

\section{Findings}

Our data analysis led to the identification of four distinct whole story frames pertaining to inclusive innovation among agricultural practitioners in Kenya: A support frame, a resource frame, a compatibility frame, commercialize and a power relations frame. 


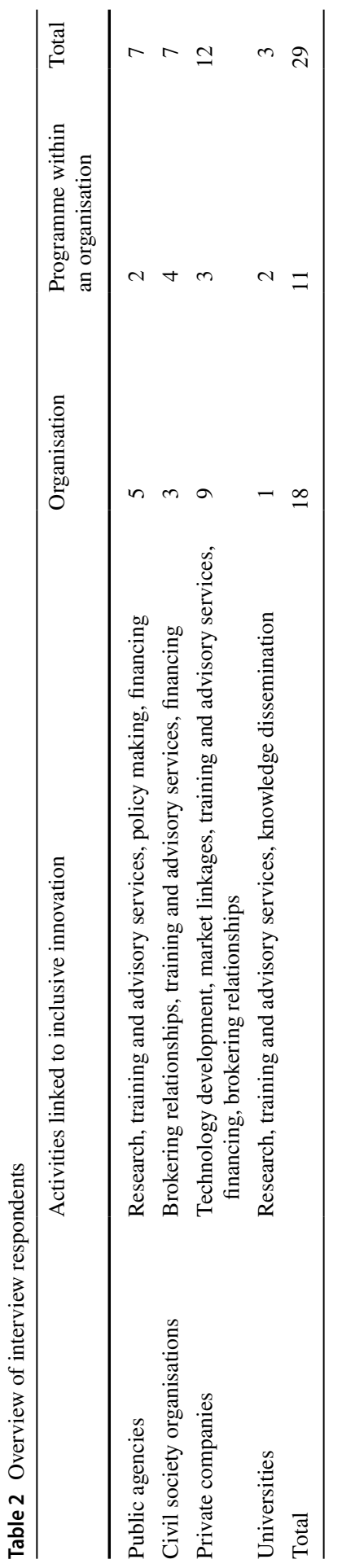




\section{How Organisations in Kenyan Agriculture Frame Inclusive Innovation}

\section{A Support Frame}

Within this frame, innovation is highlighted as a process that should support different actors in the agricultural sector such as through funding, training, research and advisory services. Mostly ascribed to by state actors and universities, the support frame constructs the problem of exclusion in the innovation process as the lack of sufficient skills, knowledge and financial resources to offer necessary support all the actors within the agricultural sector as illustrated by the following quote:

From around 2002, we have never employed staff. So right now, our numbers have really gone down. And because our numbers have gone down it is becoming a challenge to reach some areas [...] we had this maize...lethal necrosis disease for maize. It popped up out of nowhere and it sort of like wiped out our success in terms of the varieties that we had developed for maize. (D12, Government agency program manager).

The reason for exclusion is thought to be large numbers of those who require support due to the prevalence of smallholder farms as indicated below:

Actually, the rural economy is based on agriculture, whether it is productive or not. It is a way of life, let me say so. (D12, Government agency program manager).

In addition, emphasis is laid on the unique and challenging conditions in some regions such as arid and semi-arid lands which make it difficult to offer support.

Solutions highlighted within this frame include agglomeration of actors that need support into groups as a way of enhancing reach. It also stresses the need for specialised support to different groups of actors as illustrated below:

[...] those ones were very vulnerable. We tried giving them goats which all died... All they need is handouts. So, some were able to develop the skills for business, others could not. It's just like in a classroom setup. There are those who will grasp the concepts, while others will not because of other issues. (D21, County government official).

\section{A Resource Frame}

This frame constructs agriculture as a skill, knowledge and capital intensive 'profession' that requires substantial material and immaterial resources such as capital, knowledge on business and management practises, knowledge on agronomy and soil management as well as marketing skills. Commercial enterprises and some development practitioners mainly ascribe to this frame and inclusion is problematized as the inefficiency created by actors who do not have enough resources to participate in the innovation process. As demonstrated by the quote below, including smallholder 
dairy farmers in the dairy value chain is framed as a challenge for producing quality milk:

Of the milk we receive here in Kenya, 60 to $70 \%$ is produced by smallholders. And we see that smallholders have tremendous problems in delivering quality milk.[...] Milk is chilled late, delivered late and the total plate count [microbial contamination] exceed the standard specifications by far". (D32, Manager of a food company).

In addition, perceptions and attitudes is also considered to be a problem that leads to the exclusion of some actors from the innovation process as demonstrated below:

the issue with these incentives is that the farmers tend to develop a dependency syndrome...it takes away their ability to think for themselves. Yet commercialization requires one to be an entrepreneur, someone who can think and act on their own with the ability to setup structures that can commercialise their enterprise. Not someone who is dependent on handouts. That is what is killing the sector". (D21, County government official).

Recommended solutions within this frame narrative highlight the need to provide required resources to those that need it to enable them to participate in the innovation process as well as benefit from innovations developed elsewhere. This may be through training and advisory services, market linkages or providing farm inputs. Inclusion within this frame is based on the logic of enabling as many actors as possible to participate in these markets, if they possess or can acquire the needed expertise, knowledge and material resources.

\section{A Compatibility Frame}

This frame is mostly ascribed to by NGOs and research institutions. The problem is constructed as incompatibility between the innovation processes pursued by development planners and other organisations and the interests and priorities of farming households and communities. For example, the quote below shows how the approach by development practitioners may not necessarily be prioritised by farmers:

...I have had experience with several rural homesteads in Kenya where we are forcing them to be commercial farmers, yet the number one duty of a small farmer is the to provide food for their family. But now we are telling them that they need to focus on selling. I have found this to be a conflict...the making of profit while also focusing on the needs of your family as a farmer". (B22, Social entrepreneurship consultant).

Similarly, some local contexts are highlighted as unsuitable for certain innovations or approaches by agricultural practitioners. There is, therefore, incompatibility between the new skills, knowledge and technologies provided by organisations and local contexts within which they are implemented leading to the exclusion of the latter from benefiting from or participating in the innovation process. 
Reasons for this incompatibility is perceived to be a physical and ideological gap between how agricultural practitioners understand and practise innovation and how their clients or beneficiaries such as farmers understand and practise the same. The quote below for instance demonstrates a perceived incompatibility between research and farmers' needs:

The university has always been assumed to be a place that is only for scholars, where they [farmers] do not have much to learn. So, we are trying to open up the space for the farmers. Students come up with several research problems. But do we really consider the farmers when we are coming up with these? [...] So that is really the gap. (D26, University program officer).

The compatibility frame emphasises bridging of the physical and ideological gap between development practitioners and their clients or beneficiaries as a solution to make innovations inclusive. It also highlights the need to understand local contexts and the inclusion beneficiaries and clients in the inception, design and delivery of agricultural interventions. The practitioner below for example emphasises the need to facilitate interaction between agricultural extension officers and farmers to facilitate shared learning:

We don't call ourselves a training institution. We offer a learning environment for farmers and also for the agricultural extension officers. Agriculture is very dynamic; the key players are the farmers who have been practicing it for a long time. They are very experienced and have a lot of knowledge... a lot of information. Of course, the extension officers also have skills and information. So, we offer a learning opportunity for those farmers to be able to interact with agriculture officers and be able to learn. (D20, NGO director).

\section{A Power Relations Frame}

According to this frame, innovation and its prospects of being inclusive is related to issues of power and control. It is predominantly ascribed to by civil society organisations and some state agencies such as local governments. The problem is constructed as the unequal control over the innovation process including unequal access to knowledge, technologies, social arrangements and financial capital by different actors. For example, the quote below shows how women and youth are considered to be excluded from participating in agricultural production and knowledge creation compared to men and the elderly due to unequal control over land and decision making:

Women don't own land in the country. The youth also don't own land unless the father as the head of the household subdivides the land to the children or however is around when he gets old or something [...] so they [women and youth] don't even have the power to make decisions over what to plant, what inputs they want to buy, over what they need to do... (D19, Development agency program manager). 
Furthermore, unequal control over resources is said to lead to opportunism by dominant actors, lack of trust and strained relations which restricts the extent to which exchange of knowledge and other resources between dominant and other actors occur. Reasons for exclusion within this frame are said to include preexisting inequalities is social structures, cultural norms and financial disparity among actors.

As indicated by the quote below, the power frame highlights solutions that are related to the empowerment of actors that are marginalised from control over resources:

...when we work with a group, apart from giving them the technical capacity, we also empower them to be able to mobilise resources on their own. For some, we have written grant proposals together with them. We also train them on how to be able to do business plans on their own as an exit strategy. (D4, University programme director).

\section{Synthesis of the Empirical Frames}

Our data have revealed four frames of inclusive innovation prevalent among agricultural organisations in Kenya as summarised in Table 3 below.

There are two main inferences that can be drawn from these empirical frames. First, while there may be implicit alignments to certain frames depending on the type of organisation, organisations do not exclusively ascribe to one frame. For instance, state agencies, including local governments mainly ascribe to a support narrative which is likely because they have the mandate to indiscriminately support all actors within the agricultural sector. However, they also ascribe to a resource as well as power and relationships frame in their construction of problems and solutions for inclusive innovation.

Secondly, we do not find coherence between the way the problem is constructed and the type of solutions that are recommended in the empirical frames. The resource frame highlights the local problem of lack of sufficient resources by farmers and other community-based actors to participate efficiently in input and output markets and the role of the private sector in providing solutions. The support frame in contrast emphasises the external problem of lack of enough capacity, initiatives and knowledge to support the innovation process and the role of public actors such as government agencies and research institutions in providing the solution. Across the four empirical frames, problems are emphasised as occurring at the local level such as actors who lack adequate support, resources, knowledge or power. Recommended solutions on the other hand highlight the role of external knowledge, capacity and initiatives in making innovations inclusive. This includes enabling markets and capacity building of local actors by external actors (resource frame), collaboration among external actors through partnerships (support frame), adapting external programs and interventions to respond to the needs and interests of local actors (compatibility frame) and bridging the power gap between both market and nonmarket external and local actors (power and relationships frame). 


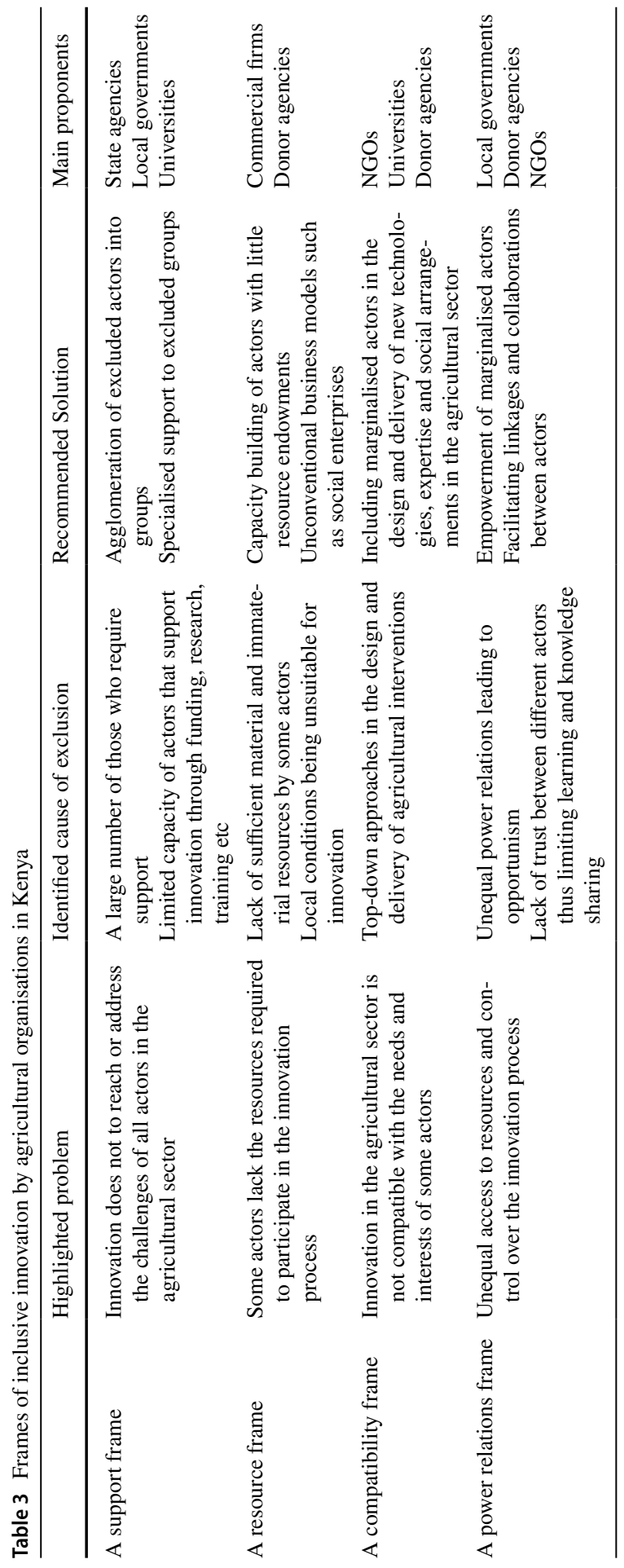

称 


\section{How Do the Empirical Frames Compare to Existing Theoretical Narratives About Inclusive Innovation?}

We earlier identified a BOP, grassroots and political economy narratives that are found in literature. Apart from the resource frame which aligns with the BOP narrative, there is a divergence between the theoretical narratives about inclusive innovation and the frames constructed about inclusive innovation by organisations in the Kenyan agricultural sector.

The figures below juxtapose the empirical frames against the theoretical narratives of inclusive innovation regarding how the problem is defined (Fig. 2a) and the recommended solutions (Fig. 2b), respectively. Regarding the problem frames, we find the resource frame to be aligned to the BOP narrative where access to input and output markets is emphasised as a problem that leads to exclusion of actors with little resource endowments. The resource frame considers base of the pyramid actors to be farmers, traders and other actors in the agricultural value chain that lack the knowledge, expertise, material resources or financial capital to be able to participate in developing an economically efficient agricultural sector. The compatibility frame is linked to a grassroots narrative where the control of agricultural knowledge, interventions, projects and business models by dominant actors such as state agencies and research institutions is emphasised. This excludes grassroots actors local in the agricultural sector such as smallholder farmers and food distributors from the innovation process. In contract to the grassroots narrative, it does not emphasise locally based initiatives and knowledge in making innovation inclusive but instead calls for bridging of the ideological, physical and material gap between grassroots actors and other actors in the innovation process. The support frame partly aligns to a political economy frame where the civic problem of lack of proper social structures is highlighted. However, it lays more emphasis on the inadequacy of external public actors such as local governments and development practitioners compared to the political economy narrative which highlights both external and local civic problems. The power and relationships frame also partly aligns to the political economy frame in constructing the problem as both external and local. However, its emphasis on relationships between actors as a problem is not aligned to any of the existing theoretical narratives.

While the theoretical narratives highlighted both external and local initiatives, knowledge and capacity as solutions to making innovation inclusive, we find that organisations in Kenyan agriculture in contrast lay more emphasis on external capacity, knowledge and initiatives as solutions despite the fact that problems at the local level are identified. This could be because they frame solutions based on their roles as practitioners who design and implement interventions.

\section{Discussion}

In the next sections, we discuss these findings and their implications for academic research, agricultural policy and practises and future inquiry. 

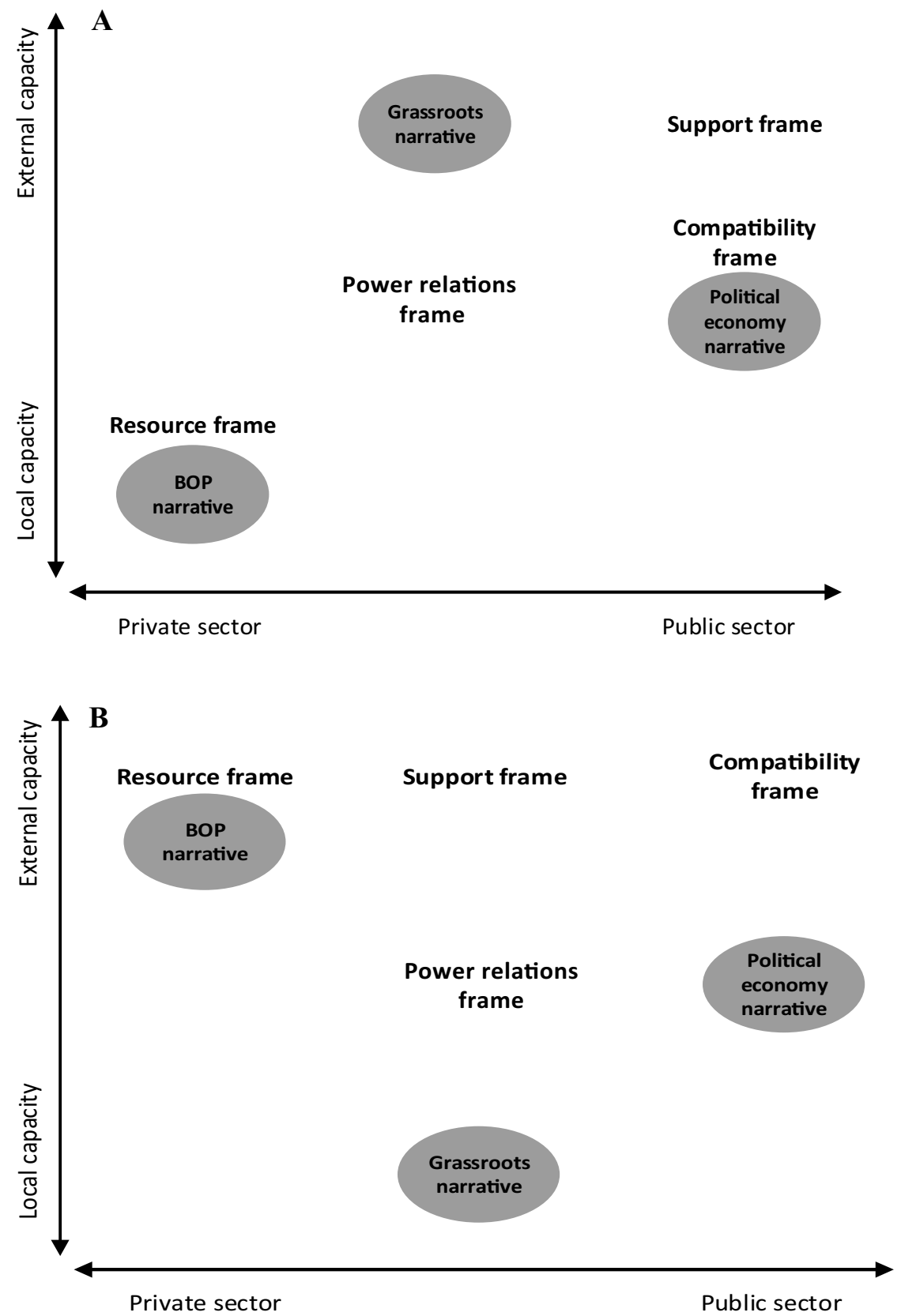

Fig. 2 a Problem frames and narratives. b Solution frames and narratives 


\section{The Hybridity of Inclusive Innovation Narratives}

Juxtaposing the three theoretical narratives of inclusive innovation with the framing of the concept by different organisations in the Kenyan agricultural sector shows no clear alignment. Instead, the concept of inclusive innovation is framed through a cross-fertilisation of different aspects of the theoretical narratives. The resulting empirical narratives are, therefore, a hybrid of the existing theoretical narratives in the ways that problems and solutions are constructed. For instance, the support frame by organisations in Kenya draws from the BOP narrative by constructing the problem of exclusion in the innovation process as the limited access to the resources such as finance and knowledge that are required for innovation by certain actors. However, it also draws from the political economy narrative that looks at the broader systemic problems related to exclusion. Resource constraints are, therefore, not limited to actors at the 'bottom of the economic pyramid' but also those at the 'top of the economic pyramid' such as government agencies and research institutions which lack the capacity to address the challenges at the BOP through innovation.

There is, therefore, a need to think beyond the problem of inadequate local capacity as proposed by the BOP narrative and reflect on other forms of resource constraints such as those at the top of the economic pyramid. For instance, while narratives about inclusive innovation have focused on empowerment of 'marginalised' actors such as the youth, women, informal sector actors or remote communities, less emphasis has been laid on building the capacity of external actors such as the state or research institutions to be able to be inclusive. This limits the range of possible solutions to an innovation process that is inclusive.

While the existence of different narratives within an innovation process has been well documented (e.g. Gupta et al. 2015; Cabral 2016; Osei-Amponsah et al. 2018; Pansera and Owen 2018), their implications for innovation practises and social inclusion need to be examined. Empirical studies in Gambia has revealed that development actors, including farmers are often aware of the contradictions between various narratives and interests that guide agricultural policy and development (Wadham et al. 2019). Usually, actors try to accommodate other existing narratives within their own narratives to avoid conflict (Osei-Amponsah et al. 2018). We add to this discourse by illustrating that narratives are complete storylines of a problem containing a history of an issue, what caused it and what solutions are proposed and different actors accommodate alternative narratives by weaving it into their own thus creating a hybrid narrative that other actors can identify with at least in part. Organisations may, therefore, appear to be having the same solution even the though the problems being addressed are different. This creates a false sense of alignment to mandates and objectives between different organisations.

\section{Do Existing Theoretical Narratives of Inclusive Innovation Represent Reality?}

It has been pointed that the dominant narrative of resource poor actors and the role of economic growth in alleviating this resource scarcity has been inadequate 
as evidenced by large groups of society that are still excluded from the benefits of economic growth. As a solution, alternative approaches have been called for (Baud 2016). Over time, these alternative models of growth, innovation and social development have been explored and developed (Godin 2017; Pansera and Owen 2018) Our study has revealed that there currently exists at least two main alternative narratives to the economic growth theory (what we call the BOP narrative). One highlights the power relationships between actors and the need to overcome these, while the other emphasises grassroots alternatives to orthodox growth theories. However, empirical investigation reveals that these existing theories do not align with how innovation and social inclusion is conceptualised in reality which calls for a rethinking of the narratives that inform policy and practise of inclusive innovation.

In the case of Kenyan agriculture, there is a significant mismatch between the narratives of inclusive innovation that exist in literature and the ones that exist in practise. The empirical narratives are broader in scope and highlight different aspects of solutions and problems compared to the narratives found in literature. We also find a power and relationships frame which does not fit within any of the existing theoretical narratives in the way the problems and solutions to inclusive innovation are constructed. Existing models of inclusive innovation are usually derived from innovation discourses where issues of unequal power relations are rarely examined (Ros-Tonen et al. 2015; Meagher 2018). We further reveal that trust and relationships between actors is inhibited by these unequal power relationships which limit the extent to which knowledge or technologies can be shared inclusive innovation processes.

\section{The (Non) Universality of Inclusive Innovation Narratives and Models}

Our study also contributes to the literature that examines the nexus between society and innovation. It has been pointed out that innovation, including new technologies, expertise and social arrangements, emerge in accordance to the social contexts, values and aspirations of the society where it is developed (Bijker and Law 1992; Klein and Kleinman 2002). As a result, innovation from one region of the world may not be transferable or relevant to other regions (Macnaghten et al. 2014; Klerkx et al. 2017; Pfotenhauer and Jasanoff 2017). Rusca et al. (2015) for example have pointed out that generic models of inclusive innovation developed in industrially advanced countries are usually out of touch with realities in less industrialised countries where they are transferred. One of the suggested ways of overcoming this challenge has been the adaptation of such models to local conditions and contexts such as through use of local expertise and resources (Benouniche et al. 2014; Cleaver 2017). Our study shows one of the reasons for the misalignment between models and the social contexts in which they are applied is difference in the narratives about the problems being solved and solutions being recommended. This does not call for an inclusive narrative of inclusive innovation' but rather 'an inclusion of other narratives of inclusive innovation'. 


\section{Conclusion}

Our objective was to examine the narratives about inclusive innovation that exist in literature and within the Kenyan agricultural sector development. Our analysis has revealed four narratives within the Kenyan agricultural sector which are a complex hybrid of existing theories about innovation and social inclusion. Furthermore, we find that the empirical narratives are more and broader in scope compared to what is found in literature. An elaborated theory of inclusive innovation that links all the different narratives as proposed by some authors (e.g. Klochikhin 2012; Gupta et al. 2015) may be challenging given the extensive scope of these narratives. The different narratives of innovation and social inclusion, however, provide an opportunity to provide a variety of solutions to different problems of social exclusion. The ambiguity surrounding the concept of inclusive innovation is due to different existing narratives and the concept. Rather than trying to clarify the ambiguity, further research could provide insights on how different pathways of inclusive innovation can be pursued simultaneously rather than merging the different narratives into an all-encompassing theory of inclusive innovation.

Development planners, including government agencies, NGO's, commercial enterprises and research institutions experiment with various approaches to development. These organisations not only pursue different interests and strategic goals but also work within certain discourses that construct or label certain actors as excluded. A variety of narratives is required in order to broaden the scope of possibilities for inclusive innovation processes especially in countries such as Kenya that are that are characterised by diversity and uncertainty. For example, new crop varieties could be developed with enough technical capacity and social arrangements to allow farmers to experiment with them. As Illich, (1973:11) points out, "people need new tools to work with rather than tools that 'work' for them".

\section{Limitations and Future Research}

Our study was limited in scope as it focused on organisations involved in development planning and implementation such NGO's, development agencies, universities, government agencies and private businesses. Further inquiry could reveal the narratives of inclusive innovation that exist among 'clients' or 'beneficiaries' of such development programs and how they relate to the theoretical and empirical narratives presented in this study. By using framing analysis, we limit our study to the narratives that people and organisations construct about inclusive innovation, but not the power dynamics and negotiations behind them. Other methods of analysing discourse could further reveal the agendas and interests behind these empirical narratives. We also limit our study to understanding the narratives and frames of inclusive innovation, but not how these translate into certain institutional logics and actions on the ground. Further research could explore how these frames are translated into practise and what elements of inclusive innovation are employed. 
Acknowledgements This study was conducted as part of PhD research under the 3R Kenya project. The project was funded by the Embassy of the Kingdom of the Netherlands in Nairobi, Kenya, within the framework of the Agriculture and Food \& Nutrition Security program, whose support is appreciated.

\section{Compliance with Ethical Standards}

Conflict of interest The authors state that there is no conflict of interest.

Open Access This article is licensed under a Creative Commons Attribution 4.0 International License, which permits use, sharing, adaptation, distribution and reproduction in any medium or format, as long as you give appropriate credit to the original author(s) and the source, provide a link to the Creative Commons licence, and indicate if changes were made. The images or other third party material in this article are included in the article's Creative Commons licence, unless indicated otherwise in a credit line to the material. If material is not included in the article's Creative Commons licence and your intended use is not permitted by statutory regulation or exceeds the permitted use, you will need to obtain permission directly from the copyright holder. To view a copy of this licence, visit http://creativecommons.org/licen ses/by/4.0/.

\section{References}

African Union Commission. 2014. Science, technology and innovation strategy for Africa 2024 (STISA2024). Addis Ababa.

Altuna, N., et al. 2015. Managing Social Innovation in For-Profit Organizations: The Case of Intesa Sanpaolo. European Journal of Innovation Management 18 (2): 258-280.

Arora, S., and H. Romijn. 2012. The Empty Rhetoric of Poverty Reduction at the Base of the Pyramid. Organization 19 (4): 481-505.

Arza, V., and P. van Zwanenberg. 2014. Innovation in Informal Settings but in Which Direction? The Case of Small Cotton Farming Systems in Argentina. Innovation and Development 4 (1): 55-72.

Banks, N., D. Hulme, and M. Edwards. 2015. NGOs, States, and Donors Revisited: Still Too Close for Comfort? World Development 66: 707-718.

Baud, I. 2016. Moving Towards Inclusive Development? Recent Views on Inequalities, Frugal Innovations, Urban Geo-Technologies, Gender and Hybrid Governance. The European Journal of Development Research 28 (2): 119-129.

Benouniche, M., M. Zwarteveen, and M. Kuper. 2014. Bricolage as Innovation: Opening the Black Box of Drip Irrigation Systems. Irrigation and Drainage 63 (5): 651-658.

Bijker, W., and J. Law. 1992. Shaping Technology/Building Society: Studies in Sociotechnical Change. Cambridge, MA: MIT Press.

Borda-Rodriguez, A., and H. Johnson. 2019. Inclusive Development and Co-operatives. European Journal of Development Research. https://doi.org/10.1057/s41287-019-00249-9.

Bryden, J., et al. 2017. Inclusive Innovation in the Bioeconomy: Concepts and Directions for Research. Innovation and Development 7 (1): 1-16.

Cabral, L. 2016. Brazil's Tropical Solutions for Africa: Tractors, Matracas and the Politics of "appropriate technology". European Journal of Development Research 28 (3): 414-430.

Cacciatore, M.A., D.A. Scheufele, and S. Iyengar. 2016. The End of Framing as we Know it ... and the Future of Media Effects. Mass Communication and Society 19 (1): 7-23.

Campbell, M.C., and J.S. Docherty. 2003. What's in a Frame (That Which We Call a Rose by Any Other Name Would Smell as Sweet). Marquette Law Review 87: 769.

Chataway, J., R. Hanlin, and R. Kaplinsky. 2014. Inclusive Innovation: An Architecture for Policy Development. Innovation and Development 4 (1): 33-54.

Christoplos, I. 2010. Mobilising the Potential of Rural and Agricultural Extension. FAO Report. Rome (Italy) FAO/GFRAS, pp. 1-58.

Cleaver, F. 2017. Development Through Bricolage. London: Routledge.

Cozzens, S., and J. Sutz. 2014. Innovation in Informal Settings: Reflections and Proposals for a Research Agenda. Innovation and Development 4 (1): 5-31. 
Danse, M., et al. 2020. Unravelling Inclusive Business Models for Achieving Food and Nutrition Security in BOP Markets. Global Food Security 24: 100354.

De Bruycker, I. 2017. Framing and Advocacy: A Research Agenda for Interest Group Studies. Journal of European Public Policy 24 (5): 775-787.

Dewulf, A., et al. 2009. Disentangling Approaches to Framing in Conflict and Negotiation Research: A Meta-paradigmatic Perspective. Human Relations 62 (2): 155-193.

Entman, R.M. 1993. Framing: Toward Clarification of a Fractured Paradigm. Journal of Communication 43 (4): 51-58.

Fressoli, M., et al. 2014. When Grassroots Innovation Movements Encounter Mainstream Institutions: Implications for Models of Inclusive Innovation. Innovation and Development 4 (2): 277-292.

Gee, J. P. (2014). An introduction to discourse analysis: Theory and method. Routledge.

Godin, B. 2017. Models of Innovation: The History of an Idea. Cambridge, MA: The MIT Presss.

Gupta, J., N.R.M. Pouw, and M.A.F. Ros-Tonen. 2015. Towards an Elaborated Theory of Inclusive Development. European Journal of Development Research 27 (4): 541-559.

Heeks, R., C. Foster, and Y. Nugroho. 2014. New Models of Inclusive Innovation for Development. Innovation and Development 4 (2): 175-185.

Heeks, R., F. Malik, S. Morgan, and B. Nicholson. 2020. Understanding and managing business-development hybrids: an institutional logics case analysis. Development Studies Research 7 (1): 31-49.

Higgins, V., and C. Richards. 2019. Framing Sustainability: Alternative Standards Schemes for Sustainable Palm Oil and South-South Trade. Journal of Rural Studies 65: 126-134.

Hossain, M. 2016. Grassroots Innovations: A Systematic Review of Two Decades of Research. Journal of Cleaner Production 137: 973-981.

Illich, I. 1973. Tools for Conviviality. London: Calder and Boyars.

Kanu, B.S., A.O. Salami, and K. Numasawa. 2014. Inclusive Growth; An Imperative for African Agriculture. African Development Bank Group. Rural Outreach Program.

Karanja, E., et al. 2017. Supporting Farmer Innovation to Enhance Resilience in the Face of Climate Change in Farming Systems in Machakos and Kitui Counties, Kenya, 677-688. Cham: Springer.

Kenis, A., and E. Mathijs. 2014. De)politicising the Local: The Case of the Transition Towns movement in Flanders (Belgium. Journal of Rural Studies 34: 172-183.

Kilelu, C.W., L. Klerkx, and C. Leeuwis. 2014. How Dynamics of Learning are Linked to Innovation Support Services: Insights from a Smallholder Commercialization Project in Kenya. Journal of Agricultural Education and Extension 20 (2): 213-232.

Klein, H.K., and D.L. Kleinman. 2002. The Social Construction of Technology: Structural Considerations. Science, Technology, \& Human Values 27 (1): 28-52.

Klerkx, L., et al. 2017. Replication and Translation of Co-innovation: The Influence of Institutional Context in large International Participatory Research Projects. Land Use Policy 61: 276-292.

Klochikhin, E.A. 2012. Linking Development and Innovation: What Does Technological Change Bring to the Society. European Journal of Development Research 24 (1): 41-55.

Knorringa, P., et al. 2016. Frugal Innovation and Development: Aides or Adversaries? European Journal of Development Research 28 (2): 143-153.

Levidow, L., and T. Papaioannou. 2017. Which Inclusive Innovation? Competing Normative Assumptions Around Social Justice. Innovation and Development 8 (2): 1-18.

Lowe, P., et al. 2019. Expertise in Rural Development: A Conceptual and Empirical Analysis. World Development 116: 28-37.

Macnaghten, P., et al. 2014. Responsible Innovation Across Borders: Tensions, Paradoxes and Possibilities. Journal of Responsible Innovation 1 (2): 191-199.

Meagher, K. 2018. Cannibalizing the Informal Economy: Frugal Innovation and Economic Inclusion in Africa. European Journal of Development Research 30 (1): 17-33.

Merrey, D.J., and S. Cook. 2012. Fostering Institutional Creativity at Multiple Levels: Towards Facilitated Institutional Bricolage. Water Alternatives 5 (1): 1-19.

Minh, T.T., et al. 2014. Niche Action and System Harmonization for Institutional Change: Prospects for Demand-Driven Agricultural Extension in Vietnam. Journal of Rural Studies 36: 273-284.

MoALF, K. 2019. Agricultural Sector Transformation and Growth Strategy.

Moschitz, H., et al. 2015. Learning and Innovation Networks for Sustainable Agriculture: Processes of Co-evolution, Joint Reflection and Facilitation. Journal of Agricultural Education and Extension 21 (1): $1-11$.

Nemes, G., and A.M. Augustyn. 2017. Towards Inclusive Innovation in the European Context-The Innovation Capacity of Alternative Networks for Sustainable Agriculture. Innovation and Development 7 (1): 133-152. 
Onsongo, E.K., and J. Schot. 2017. Inclusive Innovation and Rapid Sociotechnical Transitions: The Case of Mobile Money in Kenya. SSRN Electronic Journal.

Osei-Amponsah, C., A. van Paassen, and L. Klerkx. 2018. Diagnosing Institutional Logics in Partnerships and How they Evolve Through Institutional Bricolage: Insights from Soybean and Cassava Value Chains in Ghana. NJAS - Wageningen Journal of Life Sciences 84: 13-26.

Pansera, M., and F. Martinez. 2017. Innovation for Development and Poverty Reduction: An Integrative Literature Review. Journal of Management Development 36 (1): 2-13.

Pansera, M., and R. Owen. 2018. Framing Inclusive Innovation Within the Discourse of Development: Insights from Case Studies in India. Research Policy 47 (1): 23-34.

Pansera, M., and S. Sarkar. 2016. Crafting Sustainable Development Solutions: Frugal Innovations of Grassroots Entrepreneurs. Sustainability (Switzerland) 8 (1): 1-51.

Parkinson, S. 2009. When Farmers Don't Want Ownership: Reflections on Demand-Driven Extension in Sub-Saharan Africa. The Journal of Agricultural Education and Extension 15 (4): 417-429.

Peredo, A.M., N. Montgomery, and M. McLean. 2017. The BoP Business Paradigm: What it Promotes and What It Conceals. Oxford Development Studies 46 (3): 411-429.

Pfotenhauer, S., and S. Jasanoff. 2017. Panacea or Diagnosis? Imaginaries of Innovation and the "MIT Model" in Three Political Cultures. Social Studies of Science. 47 (6): 783-810.

Poole, N.D., M. Chitundu, and R. Msoni. 2013. 'Commercialisation: A Meta-approach for Agricultural Development Among Smallholder Farmers in Africa? Food Policy 41: 155-165.

Prahalad, C.K. 2005. The Fortune at the Bottom of the Pyramid. Upper Saddle River, NJ: Wharton School Pub.

Prahalad, C.K., A. Di Benedetto, and C. Nakata. 2012. Bottom of the Pyramid as a Source of Breakthrough Innovations. Journal of Product Innovation Management 29 (1): 6-12.

Rip, A. 2018. Science Institutions and Grand Challenges of Society: A Scenario, 35-47. Wiesbaden: Springer.

Ros-Tonen, M.A.F., et al. 2015. Landscapes of Social Inclusion: Inclusive Value-Chain Collaboration Through the Lenses of Food Sovereignty and Landscape Governance. The European Journal of Development Research 27 (4): 523-540.

Rusca, M., et al. 2015. Adapting Generic Models Through Bricolage: Elite Capture of Water Users Associations in Peri-Urban Lilongwe. European Journal of Development Research 27 (5): 777-792.

Simanis, E., and S. Hart. 2011. Innovation from the Inside Out: Top 10 Lessons on the New Business of Innovation, p. 9, MIT Sloan Management Review.

Smith, A., M. Fressoli, and H. Thomas. 2014. Grassroots innovation movements: Challenges and contributions. Journal of Cleaner Production 63: 114-124.

Stoop, W.A., and T. Hart. 2005. Research and Development Towards Sustainable Agriculture by Resource-Poor Farmers in sub-Saharan Africa: Some Strategic and Organisational Considerations in Linking Farmer Practical Needs with Policies and Scientific Theories. International Journal of Agricultural Sustainability 3 (3): 206-216.

Stott, N., and P. Tracey. 2018. Organizing and innovating in poor places. Innovation: Management Policy and Practice 20 (1): 1-17.

Strauss, A., and J. Corbin. 1990. Basics of Qualitative Research. CA Sage: Thousand Oaks.

Swaans, K., et al. 2014. Operationalizing Inclusive Innovation: Lessons from Innovation Platforms in Livestock Value Chains in India and Mozambique. Innovation and Development 4 (2): 239-257.

Swigert-Gacheru, M. 2011. Globalizing East African Culture: From Junk to Jua Kali Art. Perspectives on Global Development and Technology 10 (1): 127-142.

Tesch, R. 1990. Qualitative Research: Analysis Types and Software Tools. New York: Falmer Press.

Thornton, P., W. Ocasio, and M. Lounsbury. 2012. The Institutional Logics Perspective: A New Approach to Culture, Structure and Process. Oxford: Oxford University Press.

Tracey, P., and N. Stott. 2017. Social Innovation: A Window on Alternative Ways of Organizing and Innovating. Innovation: Management, Policy and Practice 19 (1): 51-60.

Venot, J.-P. 2016. A Success of Some Sort: Social Enterprises and Drip Irrigation in the Developing World. World Development 79: 69-81.

Wadham, H., C. Urquhart, and R. Warren. 2019. Living with Paradox in International Development: An Extended Case Study of an International NGO. European Journal of Development Research 31 (5): 1263-1286.

Publisher's Note Springer Nature remains neutral with regard to jurisdictional claims in published maps and institutional affiliations. 